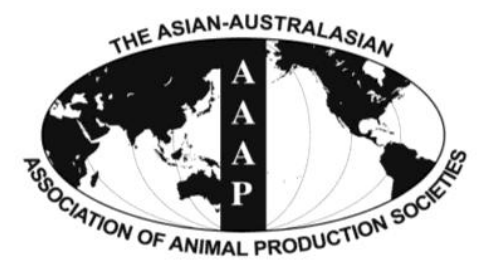

Asian-Aust. J. Anim. Sci.

Vol. 25, No. 12 : 1734-1741 December 2012

http://dx.doi.org/10.5713/ajas.2012.12249

www.ajas.info

pISSN 1011-2367 elSSN 1976-5517

\title{
Effects of Replacing Soybean Meal with Fermented Rapeseed Meal on Performance, Serum Biochemical Variables and Intestinal Morphology of Broilers
}

\author{
F. Z. Xu*, X. G. Zeng ${ }^{1}$ and X. L. Ding \\ College of Animal Science and Technology, Anhui Agricultural University, Hefei 230036, China
}

\begin{abstract}
This trial was performed to study the effects of replacing soybean meal (SBM) with fermented rapeseed meal (RSM) on growth performance, serum biochemistry variable and intestinal morphology of broilers. A total of $640 \mathrm{~d}$-old Arbor Acres broiler chicks were randomly allocated to 4 dietary treatments, 4 pens per treatment and 40 birds per pen for a 6 -wk feeding trial. In the four treatment groups, fermented RSM replaced soybean meal at $0,5,10$, and $15 \%$, respectively. On $21 \mathrm{~d}$ and $42 \mathrm{~d}$, two birds from each pen were randomly selected and slaughtered. Blood samples and sections of duodenum, jejunum, and ileum were collected for measurement of serum biochemical variables and intestinal morphology, respectively. Results showed that body weight gain (BWG) and feed conversion (FC) were significantly $(\mathrm{p}<0.01)$ poorer for birds fed the $15 \%$ fermented RSM diet than those fed with 0,5 and $10 \%$ fermented RSM diets during all periods. Compared with 0 and 5\% fermented RSM groups, IgG content in the serum of birds in 10 and $15 \%$ fermented RSM groups was improved $(\mathrm{p}<0.01)$ urea nitrogen content of serum was reduced $(\mathrm{p}<0.01)$ during both growing and finishing periods. However, IgM, phosphorus and calcium levels increased $(\mathrm{p}<0.05)$ only during the growing period. Increased $(\mathrm{p}<0.05)$ villus height was observed in the duodenum and jejunum of broilers fed the diet with $10 \%$ fermented RSM. In addition, villus height to crypt depth ratio in the jejunum was significantly higher $(\mathrm{p}<0.01)$ for birds fed the diet with $10 \%$ fermented RSM than for those fed diets with 0,5 and $15 \%$ fermented RSM. The present results suggest that RSM fermented with Lactobacillus fermentum and Bacillus subtilis is a promising alternative protein source and that it could be safely used replace up to 10\% SBM in broiler diets. (Key Words: Broiler, Fermented Rapeseed Meal, Intestinal Morphology, Serum Variables, Soybean Meal)
\end{abstract}

\section{INTRODUCTION}

Rapeseed meal (RSM) is the byproduct remaining after rapeseed is processed and the rapeseed oil is removed. The meal contains 34 to $38 \%$ crude protein and 25 to $30 \% \mathrm{NDF}$ (Bell, 1984). Furthermore, RSM contains high levels of glucosinolates (approximately 90 to $140 \mathrm{mmol} / \mathrm{kg}$ ). Upon ingestion, the glucosinolates are hydrolysed by a myrosinase enzyme present in the rapeseed to release a range of products (Cheng et al., 2004). The most common products are isothiocyanates which prevents the thyroid hormones from being iodinated and results in thyroid hormones being inactive when released into the blood stream (Guyton, 1986). If glucosinolate levels are high, impaired growth and goiter can develop, and the contents of triiodothyronine (T3) and thyroxine (T4) may be

\footnotetext{
* Corresponding Author: F. Z. Xu. Tel: +86-551-5786328, Fax: +86-551-5786611, E-mail: xufazhi1103@sina.com

${ }^{1}$ Mingguang Husbandry and Veterinary Bureau, China. Submitted May 8, 2012; Accepted Jul. 27, 2012; Revised Aug. 11, 2012
}

abnormally changed (Bell, 1984; McNeill et al., 2004). So the suitability of RSM as a protein supplement in animal feed is limited (Elangovan et al., 2001; Tripathi and Mishra, 2006).

As a result of developments in microbiology, the feed industry has found an effective and efficient method for the fermentation of RSM (Kumakura, 1993; Rajoka et al., 1998; El-Batal et al., 2000; Fadel and El-Batal, 2000; ElBatal and Abdel Karem, 2001). Considerable investigation has carried out on the use of RSM or fermented RSM to improve pig performance and its influence on serum biochemical variables (Lee and Hill, 1983; Spiegel and Blum, 1993; Canibe and Jensen, 2003; Fang et al., 2007). However, data on the effects of fermented rapeseed meal on performance in poultry are limited. Therefore, the current study was conducted to evaluate the growth performance, detect serum biochemistry variables and intestinal morphology in broilers fed diets with graded levels of fermented RSM and then to determine the optimum amount of fermented RSM in the broiler diet. 


\section{MATERIALS AND METHODS}

\section{Preparation of solid-state fermented RSM}

The Lactobacillus fermentum and Bacillus subtilis used in the study were obtained from the China Center for Industrial Microbiology, as CICC 20176 and CICC 20179. A mixed liquid culture, $\mathrm{pH} 6.5$, containing approximately 5 $\log \mathrm{cfu} / \mathrm{ml}$ Lactobacillus fermentum and Bacillus subtilis was prepared in a 1:1 ratio. A basal substrate containing 95\% rapeseed, $4 \%$ wheat bran and $1 \%$ brown sugar was mixed with the liquid culture in a ratio of $3: 1$. The mixture was packaged and sealed in a newly-developed multi-layer polythene bag ( $25 \mathrm{~kg}$ capacity) equipped with a one-way valve to allow the release of any carbon dioxide produced during fermentation (Rou Duoduo Biotechnology Co., Beijing, China). During the initial stage of fermentation, Bacillus rapidly consumed the oxygen in the bag and produced large amounts of carbon dioxide. The gas pressure from carbon dioxide was discharged through the valve but the valve did not allow external air into the bag. This process created an anaerobic environment that provided Lactobacillus with optimum conditions in which to grow and reproduce. The fermentation was held at $30 \pm 2^{\circ} \mathrm{C}$ for 30 d. Fresh fermented samples were dried at 50 to $60^{\circ} \mathrm{C}$ for $3 \mathrm{~d}$.

\section{Chemical analysis}

All analyses were performed in duplicate. Fermented RSM were sampled and analyzed for dry matter (DM) by drying at $105^{\circ} \mathrm{C}$ for $5 \mathrm{~h}$, ash by incineration at $550^{\circ} \mathrm{C}$. Crude protein $(\mathrm{CP})(\mathrm{N} \times 6.25)$ was determined according to the method of Kjeldahl. Crude Fat was extracted with diethyl ether (Wang et al., 2004). Phosphorus (P) concentrations of the samples were assayed photometrically, and calcium (Ca) and chromium concentrations were determined with an atomic absorption spectrophotometer (model 5100 PC, Perkin-Elmer, Norwalk, CT, USA). Amino acid (AA, method 982.30, AOAC International, 2006) analysis was conducted at the Biological Technology Center of Anhui Agricultural University. Gross energy was measured by an automatic adiabatic oxygen bomb calorimeter (Model 1281, Parr, Moline, IL, USA). Small peptide was determined according to the method of Marczak et al. (2003). Total isothiocyanates were measured according to the previous study (Choi et al., 2004). Briefly, a $10 \mathrm{~g}$ sample was mixed with myrosinase (Sigma St. Louis, MO, USA) to release isothiocyanates. Then analysis of isothiocyanates was performed on a HP 6890 gas chromatograph equipped with a HP 5873 mass-selective detector and a HP 6890 series auto-injector (Hewlett Packard, Wilmington, DE).

\section{Feeding trial}

All protocols used in the present experiment were approved by the Institutional Animal Care and Use Committee of Anhui Agricultural University. A total of 640 one-d-old Arbor Acres broilers of equal male and female were randomly allocated into the four dietary treatments (Table 1) of 4 replicates with 40 birds per pen. The chicks were housed in wire-floored pens $(90 \times 60 \times 40 \mathrm{~cm})$ in an environmentally controlled room with continuous light and were allowed free access to water and feed. The room temperature was maintained at $35^{\circ} \mathrm{C}$ for the first $3 \mathrm{~d}$ and was reduced $3^{\circ} \mathrm{C}$ weekly until reaching $25^{\circ} \mathrm{C}$. A temperature of $23^{\circ} \mathrm{C}$ was maintained until the end of the $42 \mathrm{~d}$ experiment. The experimental diets were fermented RSM supplied with $0,5,10$, and $15 \%$ soybean meal (SBM), respectively. This experiment was conducted in 2 phases consisting of a starter phase from d 0 to 21 and a finisher phase from d 22 to 42 . At the end of each period (d 22 and 42), birds and feed were weighed by pen. Body weight gain (BWG), daily feed intake (DFI), and feed conversion (FC) were determined from these data. The basal diet was supplemented with minerals and vitamins to meet the requirements for broilers (NRC, 1994).

\section{Blood sampling}

Blood was collected at two time periods. On d 21 and d 42 , two birds from each pen were randomly selected and killed by exsanguination. Blood samples were collected from the wing vein of the broilers and the samples were centrifuged at 3,000×g for $5 \mathrm{~min}$ and the serum was stored $-20^{\circ} \mathrm{C}$ until used.

Serum samples were evaluated for serum total protein (TP), urea nitrogen (UN), total $\mathrm{P}, \mathrm{Ca}$, and immunoglobulin A (IgA), immunoglobulin M ( $\operatorname{IgM})$, immunoglobulin $\mathrm{G}$ ( $\mathrm{IgG})$, triiodothyronine (T3), and thyroxine (T4).

\section{Sampling of intestinal tissues}

At the end of each stage, two broilers from each pen was selected randomly and slaughtered for samples after fasting with free access to water for $12 \mathrm{~h}$. The following procedures were conducted using the method of Chiang et al. (2010). Segments were removed from the duodenum, jejunum, and ileum. The middle sections of the duodenum, jejunum, and ileum were aseptically isolated, flushed with $0.9 \%$ physiological saline solution, fixed with $10 \%$ neutralbuffered formalin. Each sample was prepared after staining with hematoxylin and eosin and using standard paraffin embedding procedures. The prepared slices were observed with an electron microscope (CK 40, Olympus, Tokyo, Japan) and imaged. Morphological indices were measured using an image processing and analysis system (Version 1, Leica Imaging System Ltd, Cambridge, UK).

Measurement of serum immunoglobulin concentrations

The serum IgG, IgM and IgA contents were determined 
Table 1. Ingredient composition and nutrient content (\%, as fed basis) of experimental diets

\begin{tabular}{|c|c|c|c|c|c|c|c|c|}
\hline \multirow[b]{2}{*}{ Items } & \multicolumn{4}{|c|}{ Starter phase (1 to $21 \mathrm{~d})$} & \multicolumn{4}{|c|}{ Finisher phase ( 22 to $42 \mathrm{~d}$ ) } \\
\hline & $\begin{array}{c}0 \% \\
\text { fermented } \\
\text { RSM }\end{array}$ & $\begin{array}{c}5 \% \\
\text { fermented } \\
\text { RSM }\end{array}$ & $\begin{array}{c}10 \% \\
\text { fermented } \\
\text { RSM }\end{array}$ & $\begin{array}{c}15 \% \\
\text { fermented } \\
\text { RSM }\end{array}$ & $\begin{array}{c}0 \% \\
\text { fermented } \\
\text { RSM }\end{array}$ & $\begin{array}{c}5 \% \\
\text { fermented } \\
\text { RSM }\end{array}$ & $\begin{array}{c}10 \% \\
\text { fermented } \\
\text { RSM }\end{array}$ & $\begin{array}{c}15 \% \\
\text { fermented } \\
\text { RSM }\end{array}$ \\
\hline \multicolumn{9}{|l|}{ Ingredients } \\
\hline Corn & 54.15 & 53.85 & 54.15 & 53.85 & 58.46 & 58.65 & 59.15 & 59.25 \\
\hline $\mathrm{SBM}^{1}$ & 34.5 & 29.8 & 24.5 & 19.8 & 31.04 & 25.85 & 20.35 & 15.25 \\
\hline Fermented RSM & 0 & 5 & 10 & 15 & 0 & 5 & 10 & 15 \\
\hline Fish meal & 4 & 4 & 4 & 4 & 2.5 & 2.5 & 2.5 & 2.5 \\
\hline Soybean oil & 3.2 & 3.2 & 3.2 & 3.2 & 3.2 & 3.2 & 3.2 & 3.2 \\
\hline Limestone & 1.1 & 1.1 & 1.1 & 1.1 & 1 & 1 & 1 & 1 \\
\hline Dicalcium phosphate & 1.3 & 1.3 & 1.3 & 1.3 & 1.9 & 1.9 & 1.9 & 1.9 \\
\hline Premix $^{2}$ & 1 & 1 & 1 & 1 & 1 & 1 & 1 & 1 \\
\hline Salt & 0.3 & 0.3 & 0.3 & 0.3 & 0.3 & 0.3 & 0.3 & 0.3 \\
\hline Chromic oxide & 0.1 & 0.1 & 0.1 & 0.1 & 0.1 & 0.1 & 0.1 & 0.1 \\
\hline L-lysine $\cdot \mathrm{HCl}(78 \%)$ & 0 & 0.2 & 0.2 & 0.2 & 0 & 0.35 & 0.35 & 0.35 \\
\hline DL-methionine (98\%) & 0 & 0.15 & 0.15 & 0.15 & 0 & 0.15 & 0.15 & 0.15 \\
\hline \multicolumn{9}{|l|}{ Nutrient content ${ }^{3}$} \\
\hline ME (Mcal/kg) & 2.92 & 2.92 & 2.92 & 2.92 & 3.13 & 3.13 & 3.13 & 3.13 \\
\hline Crude protein & 21.75 & 21.64 & 21.56 & 21.65 & 19.62 & 19.60 & 19.69 & 19.67 \\
\hline Calcium & 1.01 & 1.03 & 1.02 & 1.00 & 0.92 & 0.97 & 0.95 & 0.89 \\
\hline Available phosphorus & 0.52 & 0.53 & 0.54 & 0.54 & 0.56 & 0.58 & 0.58 & 0.59 \\
\hline Ether extract & 5.77 & 6.75 & 6.73 & 6.70 & 5.72 & 6.77 & 6.74 & 6.70 \\
\hline Ash & 6.56 & 6.83 & 6.75 & 6.13 & 6.11 & 6.13 & 6.10 & 6.15 \\
\hline Lysine & 1.24 & 1.22 & 1.26 & 1.27 & 1.08 & 1.09 & 1.10 & 1.12 \\
\hline Methionine+cysteine & 0.98 & 1.03 & 1.02 & 1.04 & 0.83 & 0.88 & 0.89 & 0.90 \\
\hline Threonine & 0.66 & 0.67 & 0.67 & 0.68 & 0.65 & 0.66 & 0.66 & 0.66 \\
\hline
\end{tabular}

${ }^{1} \mathrm{SBM}=$ Soybean meal.

${ }^{2}$ The premix provided the following per kilogram of diet: Zinc, $80 \mathrm{mg}$; copper, $15 \mathrm{mg}$; iron, $100 \mathrm{mg}$; manganese, $90 \mathrm{mg}$; iodine, $0.85 \mathrm{mg}$; selenium, 0.45 mg; vitamin A, 18,000 IU; vitamin $\mathrm{D}_{3}, 4,000 \mathrm{IU}$; vitamin $\mathrm{E}, 35 \mathrm{IU}$; vitamin $\mathrm{K}_{3}, 3.5 \mathrm{mg}$; vitamin $\mathrm{B}_{12}, 0.015 \mathrm{mg}$; riboflavin 8 mg; pantothenic acid, $18 \mathrm{mg}$; nicotinic acid, $40 \mathrm{mg}$; Pyridoxine, $4 \mathrm{mg}$; biotin, $0.2 \mathrm{mg}$; folic acid, $0.5 \mathrm{mg}$; choline chloride, $800 \mathrm{mg}$.

${ }^{3}$ Crude protein, calcium, phosphorus, ether extract, and ash are analyzed values. The metabolizable energy and amino acid contents were calculated.

by the radial immunodiffusion technique according to Ishikawa and Nanjo (2009). Briefly, the serum samples were appropriately diluted with $50 \mathrm{mM}$ Tris- $\mathrm{HCl}$ buffer $(\mathrm{pH}$ 8.0) containing $0.14 \mathrm{M} \mathrm{NaCl}, 1 \% \mathrm{BSA}$, and $0.05 \%$ Tween 20. Each amount of $\operatorname{IgG}, \operatorname{IgM}$, and $\operatorname{IgA}$ was measured with the corresponding immunoglobulin ELISA quantitation kit and protocol (Sigma, USA), and with OPD as the peroxidase substrate.

\section{T3 and T4 levels}

Serum T3 and T4 concentrations were measured using commercial ELISA kits (Gibco, USA) according to the manufacturer's instructions. Briefly, $50 \mu \mathrm{l}$ (for T3) or $25 \mu \mathrm{l}$ (for T4) serum was added to microtiter plate wells precoated with anti-T3 or anti-T4 antibodies, and then incubated with T3-HRP or T4-HRP conjugates for $1 \mathrm{~h}$ before the wells were washed. HRP substrate was added into each well and incubated for $30 \mathrm{~min}$. The absorbance was read at $450 \mathrm{~nm}$ in a microplate reader (Model 3550-UV,
Bio-Rad). The concentrations of T3 and T4 were calculated using standard curves.

\section{Statistical analyses}

Data were subjected to analysis of variance using the GLM procedure of SAS (SAS Institute, 1996). Pen was considered as the experimental unit for the performance data while the individual bird was used as the experimental unit for serum variables and measures of intestinal morphology.

\section{RESULTS}

\section{The chemical composition of fermented RSM}

Characteristics of solid-state fermented rapeseed meal are shown in Table 2. Over the $30 \mathrm{~d}$ fermentation, the DM content of the solid-state fermented rapeseed meal dropped from $92.3 \%$ to $88.8 \%$ while the CP content was increased from $37.1 \%$ to $39.6 \%$. Crude fat increased by $1.4 \%$, but $\mathrm{Ca}$ 
Table 2. Characteristics of solid-state fermented RSM during fermentation

\begin{tabular}{lrc}
\hline Diet $^{1}$ & RSM $^{2}$ & Fermented RSM \\
\hline Dry matter (\%) & 92.3 & 88.8 \\
Crude protein (\%) & 37.1 & 39.6 \\
Isothiocyanates (mmol/kg) & 108.7 & 13.1 \\
Crude fat (g/kg) & 14.8 & 16.2 \\
Calcium (g/kg) & 8.2 & 8.3 \\
Phosphorus (g/kg) & 8.6 & 8.5 \\
Rapeseed peptides (\%) & 0.7 & 5.6 \\
Lys (\%) & 1.54 & 2.68 \\
Met+cys (\%) & 1.21 & 1.64 \\
\hline
\end{tabular}

${ }^{1}$ On a dry matter basis. ${ }^{2}$ RSM $=$ Rapeseed meal.

and $\mathrm{P}$ were unaffected. The content of AA (Lys, Met+Cys) increased by $1.14 \%$ and $0.43 \%$ after $30 \mathrm{~d}$, respectively. Isothiocyanates were reduced dramatically from 108.7 to $13.1 \mathrm{mmol} / \mathrm{kg}$. The level of small peptide in fermented RSM was increased compared with RSM (5.6\% vs $0.7 \%$ ).

\section{Growth performance}

Firstly, the performance of the broilers is presented in Table 3. There was no difference in growth performance among $0 \%$ fermented RSM, 5\% fermented RSM, and 10\% fermented RSM groups during all periods, while differences were noted between the $15 \%$ fermented RSM group and the other groups. Over the entire $42 \mathrm{~d}$ growth trial, broilers fed a diet with $15 \%$ fermented RSM had a significantly poorer FC $(p<0.01)$ and BWG $(p<0.05)$ than chicks fed a diet with $0 \%$ fermented RSM, 5\% fermented RSM and $10 \%$ fermented RSM. DFI did not differ among the treatment groups during the starter period and finishing.

\section{Serum biochemistry variables}

Secondly, serum biochemistry variables are shown in
Table 4 . When compared with those fed with $0 \%$ fermented RSM and 5\% fermented RSM groups, broilers fed $10 \%$ fermented RSM and $15 \%$ fermented RSM had lower levels of serum UN $(p<0.01)$ in both trial phases and a higher content of serum total $\mathrm{P}$ and serum $\mathrm{Ca}$ concentration $(p<0.05)$ in the starter phase. Chicks fed with $10 \%$ fermented RSM and 15\% fermented RSM had a higher level of serum $\operatorname{IgG}(\mathrm{p}<0.01)$ in both periods and $\operatorname{IgM}$ $(\mathrm{p}<0.05)$ in the 1-21-d-old period than chicks fed $0 \%$ fermented RSM and 5\% fermented RSM. While there was no significant difference between $0 \%$ fermented RSM and 5\% fermented RSM added groups. Furthermore, T3 and T4 concentrations were not affected in the experiment.

\section{Morphological measurements}

Finally, morphological measurements of the small intestinal mucosa of chicks are presented in Table 5. Increased villus height of duodenum and jejunum mucosa could be observed during the whole experimental stage of broilers fed with $10 \%$ fermented RSM ( $\mathrm{p}<0.05)$. In addition, villus height to crypt depth ratio in the jejunum was significantly higher $(\mathrm{p}<0.01)$ for birds fed $10 \%$ fermented RSM than for birds fed $0 \%$ fermented RSM, 5\% fermented RSM and $15 \%$ fermented RSM. In contrast, fermentation had no effect on crypt depth in the small intestinal mucosa of chicks either in the starter or in finisher phase. Similarly, no significant difference was observed among $0 \%$ fermented RSM and 5\% fermented RSM and $15 \%$ fermented RSM added groups.

\section{DISCUSSION}

In this study, we found that fermentation changed the nutritional characteristics of rapeseed meal (Table 2). The decline in the DM content of the solid-state fermentation

Table 3. Effect of fermented RSM on growth performance of broilers ${ }^{1}$

\begin{tabular}{|c|c|c|c|c|c|c|}
\hline Criteria & $\begin{array}{c}0 \% \\
\text { fermented } \mathrm{RSM}^{2}\end{array}$ & $\begin{array}{c}5 \% \\
\text { fermented RSM }\end{array}$ & $\begin{array}{c}10 \% \\
\text { fermented RSM }\end{array}$ & $\begin{array}{c}15 \% \\
\text { fermented RSM }\end{array}$ & SEM $^{3}$ & p-value \\
\hline \multicolumn{7}{|l|}{0 to $21 \mathrm{~d}$} \\
\hline Body weight gain (g) & $35.8^{\mathrm{a}}$ & $35.1^{\mathrm{a}}$ & $36.1^{\mathrm{a}}$ & $31.1^{\mathrm{b}}$ & 0.54 & 0.05 \\
\hline Daily feed intake (g) & 48.5 & 48.3 & 49.8 & 47.2 & 0.72 & 0.17 \\
\hline Feed conversion & $1.35^{\mathrm{a}}$ & $1.38^{\mathrm{a}}$ & $1.38^{\mathrm{a}}$ & $1.52^{\mathrm{b}}$ & 0.01 & 0.01 \\
\hline \multicolumn{7}{|l|}{22 to $42 \mathrm{~d}$} \\
\hline Body weight gain (g) & $74.1^{\mathrm{a}}$ & $75.3^{\mathrm{a}}$ & $74.3^{\mathrm{a}}$ & $63.1^{\mathrm{b}}$ & 1.78 & 0.05 \\
\hline Daily feed intake (g) & 141.2 & 143.5 & 140.3 & 134.2 & 1.63 & 0.12 \\
\hline Feed conversion & $1.91^{\mathrm{a}}$ & $1.91^{\mathrm{a}}$ & $1.89^{\mathrm{a}}$ & $2.13^{\mathrm{b}}$ & 0.02 & 0.01 \\
\hline \multicolumn{7}{|l|}{0 to $42 \mathrm{~d}$} \\
\hline Body weight gain (g) & $55.0^{\mathrm{a}}$ & $55.2^{\mathrm{a}}$ & $55.2^{\mathrm{a}}$ & $47.1^{\mathrm{b}}$ & 0.93 & 0.05 \\
\hline Daily feed intake (g) & 94.8 & 96.7 & 95.3 & 90.8 & 1.75 & 0.35 \\
\hline Feed conversion & $1.72^{\mathrm{a}}$ & $1.75^{\mathrm{a}}$ & $1.73^{\mathrm{a}}$ & $1.93^{\mathrm{b}}$ & 0.01 & 0.01 \\
\hline
\end{tabular}

${ }^{1}$ Values are presented as means; 4 pens per diet, 40 birds per pen for BGW, DFI and FC per treatment. Means within rows with different letters differ significantly $(\mathrm{p}<0.05$ or $\mathrm{p}<0.01)$.

${ }^{2} \mathrm{RSM}=$ Rapeseed meal. ${ }^{3} \mathrm{SEM}=$ Standard error of the mean. 
Table 4. Effect of fermented RSM on serum variables in broilers ${ }^{1}$

\begin{tabular}{|c|c|c|c|c|c|c|}
\hline & $\begin{array}{c}0 \% \\
\text { fermented } \mathrm{RSM}^{2}\end{array}$ & $\begin{array}{c}5 \% \\
\text { fermented RSM }\end{array}$ & $\begin{array}{c}10 \% \\
\text { fermented RSM }\end{array}$ & $\begin{array}{c}15 \% \\
\text { fermented RSM }\end{array}$ & $\mathrm{SEM}^{3}$ & p-value \\
\hline \multicolumn{7}{|l|}{$21 \mathrm{~d}$} \\
\hline Urea nitrogen $(\mathrm{mmol} / \mathrm{L})$ & $1.1^{\mathrm{a}}$ & $1.0^{\mathrm{a}}$ & $0.8^{\mathrm{b}}$ & $0.8^{\mathrm{b}}$ & 0.01 & 0.01 \\
\hline Total phosphorus (mmol/L) & $1.3^{\mathrm{a}}$ & $1.5^{\mathrm{a}}$ & $1.9^{\mathrm{b}}$ & $1.8^{\mathrm{b}}$ & 0.12 & 0.05 \\
\hline $\mathrm{Ca}(\mathrm{mmol} / \mathrm{L})$ & $2.3^{\mathrm{a}}$ & $2.4^{\mathrm{a}}$ & $2.7^{\mathrm{b}}$ & $2.7^{\mathrm{b}}$ & 0.02 & 0.05 \\
\hline Total protein $(\mathrm{g} / \mathrm{L})$ & 36.7 & 37.8 & 36.5 & 36.9 & 0.81 & 0.12 \\
\hline $\operatorname{IgG}(\mathrm{g} / \mathrm{L})$ & $0.3^{\mathrm{a}}$ & $0.3^{\mathrm{a}}$ & $0.7^{\mathrm{b}}$ & $0.7^{\mathrm{b}}$ & 0.01 & 0.01 \\
\hline $\operatorname{IgM}(\mathrm{g} / \mathrm{L})$ & $0.5^{\mathrm{a}}$ & $0.5^{\mathrm{a}}$ & $0.7^{\mathrm{b}}$ & $0.7^{\mathrm{b}}$ & 0.03 & 0.05 \\
\hline $\operatorname{IgA}(\mathrm{g} / \mathrm{L})$ & 0.2 & 0.2 & 0.3 & 0.2 & 0.02 & 0.11 \\
\hline $\mathrm{T} 3(\mathrm{mmol} / \mathrm{L})$ & 1.4 & 1.5 & 1.5 & 1.7 & 0.01 & 0.16 \\
\hline $\mathrm{T} 4$ (mmol/L) & 15.6 & 16.2 & 15.8 & 16.3 & 0.41 & 0.15 \\
\hline \multicolumn{7}{|l|}{$42 \mathrm{~d}$} \\
\hline Urea nitrogen $(\mathrm{mmol} / \mathrm{L})$ & $1.0^{\mathrm{a}}$ & $1.0^{\mathrm{a}}$ & $0.5^{\mathrm{b}}$ & $0.5^{\mathrm{b}}$ & 0.01 & 0.05 \\
\hline Total phosphorus (mmol/L) & 1.0 & 1.1 & 1.3 & 1.3 & 0.04 & 0.11 \\
\hline $\mathrm{Ca}(\mathrm{mmol} / \mathrm{L})$ & 2.7 & 2.9 & 3.3 & 3.0 & 0.03 & 0.11 \\
\hline Total protein $(\mathrm{g} / \mathrm{L})$ & 38.6 & 38.6 & 39.1 & 38.9 & 0.44 & 0.32 \\
\hline $\operatorname{IgG}(\mathrm{g} / \mathrm{L})$ & $0.2^{\mathrm{a}}$ & $0.2^{\mathrm{a}}$ & $0.4^{\mathrm{b}}$ & $0.4^{\mathrm{b}}$ & 0.01 & 0.01 \\
\hline $\operatorname{IgM}(\mathrm{g} / \mathrm{L})$ & 0.5 & 0.5 & 0.5 & 0.5 & 0.02 & 0.11 \\
\hline $\operatorname{Ig} \mathrm{A}(\mathrm{g} / \mathrm{L})$ & 0.2 & 0.3 & 0.3 & 0.3 & 0.01 & 0.16 \\
\hline $\mathrm{T} 3(\mathrm{mmol} / \mathrm{L})$ & 1.6 & 1.3 & 1.8 & 1.5 & 0.02 & 0.17 \\
\hline $\mathrm{T} 4$ (mmol/L) & 15.3 & 16.4 & 15.6 & 16.2 & 0.72 & 0.14 \\
\hline
\end{tabular}

${ }^{1}$ Values are mean for eight broilers (two birds from each pen). Means within rows with different letters differ significantly $(\mathrm{p}<0.05$ or $\mathrm{p}<0.01)$.

${ }^{2} \mathrm{RSM}=$ Rapeseed meal. ${ }^{3} \mathrm{SEM}=$ Standard error of the mean.

rapeseed meal (3.5 percentage units) was most likely caused by the consumption of carbohydrate by aerobic bacteria. The CP and crude fat concentration increased slightly $(2.5$ percentage units and 1.4 percentage units) and their increases were most likely a reflection of the decline in the DM content rather than an actual increase in content. The most significant effect of the solid-state fermentation was the dramatic reduction in the isothiocyanates content in the RSM which declined by about $83 \%$. Vig and Walia (2001) reported that after fermentation there was a reduction of $43.1 \%$ in glucosinolates. Chiang et al. (2010) showed that isothiocyanates were reduced dramatically from 119.6 to $14.7 \mathrm{mmol} / \mathrm{kg}$ in a $30 \mathrm{~d}$ fermentation. Reduction of glucosinolates during fermentation may be due to utilization of glucose and the sulphur moieties of these compounds by microbial enzymes (Tripathi and Mishra, 2006). This explanation is supported by Verbiscar et al. (1981), who reported that after $21 \mathrm{~d}$ of Lactobacillus fermentation at $26^{\circ} \mathrm{C}, 95 \%$ to $98 \%$ of glucosinolates were lowered. The content of critical AA (Lys, Met+Cys) increased by $1.14 \%$ and $0.43 \%$ after $30 \mathrm{~d}$, respectively. The content of small peptides in fermented RSM was increased by $5.6 \%$ compared with RSM, which means the fermentation process improved the nutritional value of the RSM.

Performance did not significantly differ among $0 \%$ fermented RSM, 5\% fermented RSM and 10\% fermented RSM group during all periods. But BWG and FC were significantly $(\mathrm{p}<0.01)$ poorer for birds fed $15 \%$ fermented RSM in all periods. Palander et al. (2004) showed intake of ileal digestible protein from the rapeseed-containing feeds used was lower than that from soybean feeds in growing turkeys, although protein content was calculated to be the same and no effect of feed processing method on ileal digestibility was observed. One of the problems associated with rapeseed meal has been a high fibre content leading to low digestibility and energy value (Chibowska et al., 2000). Our experimental results also showed that there was no significant difference in DFI among different treatment groups. $\mathrm{Xu}$ et al (2011) reported that DFI of ducks fed $100 \%$ fermented RSM was greater $(\mathrm{p}<0.05)$ than those of ducks fed SBM, and partial fermented RSM and BWG increased gradually in the three treatment groups with augmenting fermented RSM over in the whole study period.

Compared with those in the 0\% fermented RSM and 5\% fermented RSM groups, broilers fed $10 \%$ fermented RSM and $15 \%$ fermented RSM had lower levels of serum UN $(\mathrm{p}<0.01)$ in both trail stages and a higher content of serum total $\mathrm{P}$ and serum $\mathrm{Ca}$ concentration $(\mathrm{p}<0.05)$ in the starter phase. This may be associated with the increase of available $\mathrm{P}$ and $\mathrm{Ca}$ in fermented rapeseed meal. Such an explanation is supported by Ebune et al. (1995), Fadel and El-Batal (2000) and El-Batal and Abdel Karem (2001), who reported that several microorganisms produced phytase to reduce phytic acid content in rapeseed meal during solid state 
Table 5. Efffects of fermented RSM on small intestinal morphology ${ }^{1}$

\begin{tabular}{|c|c|c|c|c|c|c|}
\hline Items & $\begin{array}{c}0 \% \\
\text { fermented } \mathrm{RSM}^{2}\end{array}$ & $\begin{array}{c}5 \% \\
\text { fermented RSM }\end{array}$ & $\begin{array}{c}10 \% \\
\text { fermented RSM }\end{array}$ & $\begin{array}{c}15 \% \\
\text { fermented RSM }\end{array}$ & $\mathrm{SEM}^{3}$ & p-value \\
\hline \multicolumn{7}{|l|}{$21 \mathrm{~d}$} \\
\hline \multicolumn{7}{|c|}{ Villus height $(\mu \mathrm{m})$} \\
\hline Duodenum & $1,319^{\mathrm{a}}$ & $1,392^{\mathrm{a}}$ & $1,530^{\mathrm{b}}$ & $1,314^{\mathrm{a}}$ & 25.3 & 0.05 \\
\hline Jejunum & $946^{\mathrm{a}}$ & $1,001^{\mathrm{a}}$ & $1,142^{\mathrm{b}}$ & $940^{\mathrm{a}}$ & 22.2 & 0.05 \\
\hline Ileum & 432 & 446 & 485 & 487 & 12.8 & 0.18 \\
\hline \multicolumn{7}{|c|}{ Crypt depth $(\mu \mathrm{m})$} \\
\hline Duodenum & 183 & 198 & 201 & 196 & 2.3 & 0.13 \\
\hline Jejunum & 159 & 158 & 156 & 160 & 1.9 & 0.14 \\
\hline Ileum & 141 & 156 & 136 & 142 & 1.7 & 0.14 \\
\hline \multicolumn{7}{|c|}{ Villus height/crypt depth ratio } \\
\hline Duodenum & 7.2 & 7.0 & 7.6 & 6.7 & 0.08 & 0.14 \\
\hline Jejunum & $5.9^{\mathrm{a}}$ & $6.3^{\mathrm{a}}$ & $7.3^{\mathrm{b}}$ & $5.8^{\mathrm{a}}$ & 0.09 & 0.01 \\
\hline Ileum & 3.1 & 2.9 & 3.6 & 3.4 & 0.02 & 0.46 \\
\hline \multicolumn{7}{|l|}{$42 \mathrm{~d}$} \\
\hline \multicolumn{7}{|c|}{ Villus height $(\mu \mathrm{m})$} \\
\hline Duodenum & $1,455^{\mathrm{a}}$ & $1,523^{\mathrm{a}}$ & $1,658^{\mathrm{b}}$ & $1,452^{\mathrm{a}}$ & 22.1 & 0.05 \\
\hline Jejunum & $1,143^{\mathrm{a}}$ & $1,189^{\mathrm{a}}$ & $1,365^{\mathrm{b}}$ & $1,191^{\mathrm{a}}$ & 20.3 & 0.05 \\
\hline Ileum & 550 & 536 & 614 & 604 & 12.7 & 0.41 \\
\hline \multicolumn{7}{|c|}{ Crypt depth $(\mu \mathrm{m})$} \\
\hline Duodenum & 112 & 124 & 138 & 115 & 1.6 & 0.24 \\
\hline Jejunum & 129 & 128 & 123 & 122 & 1.5 & 0.28 \\
\hline Ileum & 109 & 115 & 108 & 123 & 1.3 & 0.06 \\
\hline \multicolumn{7}{|c|}{ Villus height/crypt depth ratio } \\
\hline Duodenum & 13.0 & 12.3 & 12.0 & 12.6 & 0.56 & 0.65 \\
\hline Jejunum & $8.9^{\mathrm{a}}$ & $9.2^{\mathrm{a}}$ & $11.1^{\mathrm{b}}$ & $9.7^{\mathrm{a}}$ & 0.03 & 0.01 \\
\hline Ileum & 5.0 & 4.7 & 5.7 & 4.9 & 0.12 & 0.13 \\
\hline
\end{tabular}

${ }^{1}$ Values are mean for eight broilers (two birds from each pen). Means within rows with different letters differ significantly $(\mathrm{p}<0.05$ or $\mathrm{p}<0.01)$.

${ }^{2} \mathrm{RSM}=$ Rapeseed meal. ${ }^{3} \mathrm{SEM}=$ Standard error of the mean.

fermentation. Chah et al. (1975) suggested broilers fed fermented feed utilized dietary nitrogen more efficiently than broilers fed unfermented feed. The decreased UN in serum in the current trial supports this viewpoint.

The level of serum IgM and IgG may be associated with the increase of rapeseed peptide and bioactive peptides in fermented RSM. In our experiment, rapeseed peptides content was increased from $0.7 \%$ to $5.6 \%$ over the $30 \mathrm{~d}$ fermentation. Xue et al. (2009) isolated and obtained bioactive peptides from rapeseed meal, and found that the peptides might improve immune function. Wang et al. (2003) reported that adding $3 \mathrm{~g}$ small peptides $/ \mathrm{kg}$ of basal diets fed to piglets increased the concentration of immunoglobulin. Feng et al. (2007) indicated that fermented SBM dramatically increased the $\operatorname{IgM}$ and $\operatorname{IgA}$ content in serum of broiders. Xu et al. (2011) also reported that concentrations of $\operatorname{IgM}$ and $\operatorname{IgG}$ were dramatically higher for animals fed with fermented RSM than those fed with SBM. It was reported that fermentation could degrade large-size protein to small-size peptides (Kiers et al., 2000). Data pertaining to small peptide resulting from fermented
RSM are limited, so further work needs to be done.

Our results showed that no significant differences were noted in serum T3 and T4 level among the different treatment groups $(p>0.05)$. This may be related to a reduction of isothiocyanates. The fermented RSM used in this trial only contained $13.2 \mu$ moles isothiocyanates per $g$ DM. Palander et al. (2004) reported that the relative weight of thyroid glands for turkeys was significantly higher in the RSM group than in the SBM group. Karunajeewa et al. (1990) observed increased thyroid weight even at lower rapeseed content. Lardy and Kerley (1994) reported that there was a significant linear decrease in serum T4 level in response to an increasing level of rapeseed meal. So our experimental results showed fermented RSM did not affect the function of thyroid in broilers.

In the present study, increased villus height in the duodenum and jejunum were observed in broilers supplemented with $10 \%$ fermented RSM. In addition, villus height to crypt depth ratio in the jejunum was significantly higher $(p<0.01)$ for birds fed with $10 \%$ RSM. The villus height to crypt depth ratio is a very useful parameter to 
estimate the absorption capacity of the small intestine (Montaqne and Faure, 1977). Chiang et al. (2010) reported that villus height to crypt depth ratio in the jejunum was significantly higher for birds fed with fermented rapeseed meal than for birds fed the control. Maximum digestion and absorption is believed to occur as the villus height to crypt depth ratio increases in weaned pigs (Pluske et al., 1996). Antigenic materials in diets are associated with villus atrophy and crypt hyperplasia (Miller et al., 1984).

In conclusion, the results of the current study indicated that fermentation could improve the characteristics of RSM and that fermented RSM at not more than $10 \%$ of the diet did not decrease performance of chicks, increase the level of IgG, IgM and total P and Ca content and decreased the UN content in serum. Furthermore, intestinal morphology of broilers fed with $10 \%$ fermented RSM was improved. Therefore, it was concluded that the solid-state fermented RSM could be used to replace not more than $10 \%$ SBM in the diet for broilers.

\section{ACKNOWLEDGEMENTS}

This study was supported by a grant from the National Natural Science Foundation of China under award number 31101797 and College Science Research Project of Anhui Province under award number KJ2011A107.

\section{REFERENCES}

AOAC International. 2006. Official methods of analysis of AOAC International. 18th ed. AOAC International, Gaithersburg, MD.

Bell, J. M. 1984. Nutrients and toxicants in rapeseed meal: A Review. J. Anim. Sci. 58:996-1010.

Canibe, N. and B. B. Jensen. 2003. Fermented and non-fermented liquid feed to growing pigs: Effect on aspects of gastrointestinal ecology and growth performance. J. Anim. Sci. 81:2019-2031.

Chah, C. C., C. W. Carlson, G. Semeniuk, I. S. Palmerand and C. W. Hesseltine. 1975. Growth-promoting effects of fermented soybeans for broilers. Poult. Sci. 54:600-609.

Cheng, D. L., K. Hosimoto and Y. Uda. 2004. In vitro digestion of sinigrin and glucotropeolin by single strain of Bifidobacterium and identification of digestive products. Food Chem. Toxicol. 42:351-357.

Chiang, G., W. Q. Lu, X. S. Piao, J. K. Hu, L. M. Gong and P. A. Thacker. 2010. Effects of feeding solid-state fermented rapeseed meal on performance, nutrient digestibility, intestinal ecology and intestinal morphology of broiler chickens. AsianAust. J. Anim. Sci. 23:263-271.

Chibowska, M., S. Smulikowska and B. Pastuszewska. 2001. Metabolisable energy value of rapeseed meal and its fractions for broiler chickens as affected by oil and fibre content. J. Anim. Feed Sci. 9:371-378.

Choi, M. M. F., S. M. Shuang, H. Y. Lai, S. C. Cheng, R. C. W. Cheng, B. K. B. Cheung and A.W.M. Lee. 2004. Gas chromatography-mass spectrometric determination of total isothiocyanates in Chinese medicinal herbs. Anal. Chem. Acta. 516:155-163.

Davis, G. S., K. G. Anderson and A. S. Carrol. 2000. The effects of long-term caging and molt of Single Comb White Leghorn hens of heterophil to lymphocyte ratios, corticosterone and thyroid hormones. Poult. Sci. 79:514-518.

Ebune, A., S. Al-Asheh and Z. Duvnjak. 1995. Production of phytase during solid state fermentation using Aspergillus ficuum NRRL 3135 in canola meal. Bioresour. Technol. 53:712.

Elangovan, A. V. S., V. S. Verma, V. R. B. Sastry and S. D. Singh. 2001. Effect of feeding high glucosinolate rapeseed meal to laying Japanese Quail. Asian-Aust. J. Anim. Sci. 14:13041307.

El-Batal, A. I. and H. Abdel Karem. 2001. Phytase production and phytic acid reduction in rapeseed meal by Aspergillus niger during solid state fermentation. Food Res. Int. 34:715-720.

El-Batal, A. I., M. A.Abo-State and A. Shihab. 2000. Phenylalanine ammonia lyase production by gamma irradiated and analog-resistant mutants of Rhodotorula glutinis. Acta Microbiol. Pol. 49:51-61.

Fadel, M. and A. I. El-Batal. 2000. Studies on activation of amylolytic enzymes production by gamma irradiated Aspergillus niger using some surfactants and natural oils under solid state fermentation. Pakistan J. Biol. Sci. 3:1762-1768.

Fang, Z. F., J. Peng, Z. L. Liu and Y. G. Liu. 2007. Responses of non-starch polysaccharide-degrading enzymes on digestibility and performance of growing pigs fed a diet based on corn, soya bean meal and Chinese double-low rapeseed meal. J. Anim. Physiol. Anim. Nutr. (Beri). 91:361-368.

Feng, J., X. Liu, Z. R. Xu, Y. Y. Liu and Y. P. Lu. 2007. Effects of Aspergillus oryzae 3.042 fermented soybean meal on growth performance and serum biochemical variable in broilers. Anim. Feed Sci.Technol. 134:235-242.

Guyton, A. C. 1986. The thyroid metabolic hormones. Page 897 in Medical Physiology (Ed. D. Dreibelbis). Saunders, Philadephia, PA.

Ishikawa, T. and F. Nanjo. 2009. Dietary cycloinulooligosaccharides enhance intestinal immunoglobulin A production in mice. Biosci. Biotechnol. Biochem. 73:677-682.

Karunajeewa, H., E. G. Ijagbuji and R. L. Reece. 1990. Effect of dietary levels of rapeseed meal and polyethylene glycol on the performance of male broiler chickens. Br. Poult. Sci. 31:545556.

Kiers, J. L., A. E. A. Van Laeken, F. M. Rombouts and M. J. R. Nout. 2000. In vitro digestibility of bacillus fermented soya bean. Int. J. Food Microbiol. 60:163-169.

Kumakura, M. 1993. Dose-dependency of radiation on enzyme production in Trichoderma reesei. Radiat. Environ. Biophys. 32:41-46.

Lardy, G. P. and M. S. Kerley. 1994. Effect of increasing the dietary level of rapeseed meal on intake by growing beef steers. J. Anim. Sci. 72:1936-1942.

Lee, P. A. and R. Hill. 1983. Voluntary food intake of growing pigs given diets containing rapeseed meal, from different types and varieties of rape, as the only protein supplement. Br. J. Nutr. 50:661-671. 
Marczak, E. D., H. Usui, H. Fujita, Y. J. Yang, M. Yokoo, A. W. Lipkowski and M. Yoshikawa. 2003. New antihypertensive peptides isolated from rapeseed. Peptides 24:791-798.

McNeill, L., K. Bernard and M. G. MacLeod. 2004. Food intake, growth rate, food conversion and food choice in broilers fed on diets high in rapeseed meal and pea meal with observations of the resulting poultry meat. Br. Poult. Sci. 45:519-523.

Miller, B. G., T. J. Newby, C. R. Stokes and F. J. Boame. 1984. Influence of diet on post-weaning malabsorption and diarrhoea in the pig. Res. Vet. Sci. 36:187-193.

Montaqne, J. P. and C. I. Faure. 1977. How to interpret an X-ray by upper approach of the small intestine in children. Arch. Fr. Pediatr. 34:90-104

Palander, S., M. Nasi and I. Ala-fossi. 2004. Rapeseed and soybean products as protein sources for growing turkeys of different ages. Br. Poult. Sci. 45:664-671.

Pluske, J. R., M. J. Thompson, C. S. Atwood, P. H. Bird, L. H. Williams and P. E. Hartmenn. 1996. Maintenance of villus height and crypt depth, and enhancement of disaccharide digestion and monosaccharide absorption, in piglets fed on cows' whole milk after weaning. Br. J. Nutr. 76:409-422.

Rajoka, M. I., A. Bashir, S. R. S. Hussain and K. A. Malik. 1998. $\gamma$-Ray induced mutagenesis of Cellulomonas biazota for improved production of cellulases. Folia Microbiol. 43:15-22.

SAS Institute. 1996. SAS user's guide: Statistics. Version 7.0. SAS Institute, Cary, NC, USA.
Spiegel, C. and J. W. Blum. 1993. Lower food intake is a primary cause of reduced growth rate in growing pigs fed rapeseed presscake meal. J. Nutr. 123:1562-1566.

Tripathi, M. K. and A. S. Mishra. 2006. Glucosinolates in animal nutrition: A review. Anim. Feed Sci. Technol. 132:1-27.

Verbiscar, A. J., T. F. Banigan, C. W Weber, B. L. Reid, R. S. Swingle, J. E. Trei and E. A. Nelson. 1981. Deotoxification of jojoba meal by lactobacilli. J. Agric. Food. Chem. 29:296-302.

Vig, A. P. and A. Walia. 2001. Beneficial effects of Rhizopus oligosorus fermentation on reduction of glucosinolates, fibre and phytic acid in rapeseed (Brassica napus) meal. Bioresour. Technol. 78:309-312.

Wang, J. F., Y. H. Zhu and D. F. Li. 2004. In vitro fermentation of various fiber and starch sources by pig fecal inocula. J. Anim. Sci. 82:2615-2622.

Wang, T., Y. M. Fu, J. L. Lv, H. S. Jiang, Y. P. Li, C. Y. Chen and C. M. Zuo. 2003. Effects of mini-peptides on the growth performance and the development of small intestines in weaning piglets. Anim. Husbandry \& Vet. Medicine. 6:4-8.

Xu, F. Z., L. M. Li, J. P. Xu, K. Qian, Z. D. Zhang and Z. Y. Liang. 2011. Effects of fermented rapeseed meal on growth performance and serum parameters in ducks. Asian-Aust. J. Anim. Sci. 24:678-684.

Xue, Z. H., W. C. Yu, M. C. Wu and J. H. Wang. 2009. In vivo antitumor and antioxidative effects of a rapeseed meal protein hydrolysate on an S180 tumor-bearing murine model. Biosci. Biotechnol. Biochem. 73:2412-2415. 